\title{
BEBERAPA SIFAT FISIKA KIMIA TANAH YANG BERPENGARUH TERHADAP MODEL KECEPATAN INFILTRASI PADA TEGAKAN MAHONI, JABON, DAN TREMBESI DI KEBUN RAYA PURWODADI
}

\author{
Agung Sri Darmayanti \\ Staf Peneliti di UPT BKT Kebun Raya Purwodadi, Pasuruan
}

\begin{abstract}
The research was conducted at the Purwodadi Botanical Gardens in three areas covered by the dominant vegetation Mahoni (Swietenia macrophylla), Jabon (Anthocephalus cadamba) and trembesi (Samanea saman) in January to May 2012. The purpose of this study was to obtain a model infiltration rate $(\mathrm{cm} / \mathrm{h})$ that was influed by physical and chemical properties of the soil that exist under the vegetation. Physical and chemicalparameters of soil chemical properties is observed macropore (\%), organic matter (\%), percentage of the fraction silt (\%), sand $(\%)$, and clay $(\%)$, and bulk density $(B D)\left(\mathrm{g} / \mathrm{cm}^{3}\right)$. The six factors are thought to differ indirectly because of the specification and morphology of the dominant plant species shelter. Data infiltration was collected by using the ring infiltrometer, while macroporosity tested with metylen blue method, the properties of the other physical chemical factortested by laboratory of Department of Soil, Brawijaya University. The model derived from the analysis of the regression equation using SPSS software version 17.0. The study produced three different models of infiltration rate on each plot different, they were $Y=-15,8+17,3 X 1-1,09 X 2+1,53 X 3+$ 0,001 X4 - 21,3 X6 (Mahoni's plot); $Y=-108+53,0$ X1 - 0,68 X2 + 5,27 X3 - 0,470 X4 + 59,7 X6 (Jabon's plot); Y= - 20,1 + 17,4 $X 1-1,06 X 2+1,57 X 3+0,082 X 4-21,6 X 6$ (Trembesi's plot). $Y=$ Infiltration rate $(\mathrm{cm} / \mathrm{h}), X 1=$ macropore $(\%)$, X2=organic matter $(\%)$, percentage of the fraction silt $(\%)(X 3)$, sand $(\%)(X 4)$, and $X 6=$ bulk density $\left(\mathrm{g} / \mathrm{cm}^{3}\right)$. In the equation not found factor X5 (clay fraction) helped form a model because of multicollinearity analysis obtained by assuming that the clay fraction still contains a linear relationship (correlated) with other variables.
\end{abstract}

Keywords: Infiltration rate, physical of soil, chemistry of soil, Botanic garden; Mahoni (Swietenia macrophylla), Jabon (Anthocephalus cadamba) and trembesi (Samanea saman)

\section{PENGANTAR}

Infiltrasi adalah proses aliran air (umumnya berasal dari curah hujan) masuk ke dalam tanah sebagai akibat gaya kapiler (gerakan air ke arah vertikal). Setelah lapisan tanah bagian atas jenuh, kelebihan air tersebut mengalir ke tanah yang lebih dalam sebagai akibat gaya gravitasi bumi dikenal sebagai proses perkolasi (Asdak, 2002). Air infiltrasi merupakan unsur penting dalam daur hidrologi di alam dan merupakan salah satu sumber kesediaan air di masa mendatang. Mengingat banyaknya gangguan di alam saat ini dan menyebabkan ketersediaan air tanah juga berkurang, maka peneliti tertarik untuk mengadakan penelitian pada berbagai faktor sifat fisika kimia tanah yang mempengaruhi air infiltrasi. Pengukuran laju infiltrasi di lapangan penting untuk mengetahui berapa kecepatan dan besaran masuknya atau meresapnya air secara vertikal ke dalam tubuh tanah. Laju dan daya infiltrasi merupakan suatu kajian yang penting dalam pembahasan soal konservasi tanah dan air.

Kemampuan sistem lahan meretensi air hujan sangat bergantung kepada karakteristik vegetasi yang manaunginya. Perbedaan karakter vegetasi secara lambat laun secara pasti akan mempengaruhi sifat fisika kimia tanah yang berada di bawahnya. Selain itu faktor pengolahan tanah juga diduga ikut mempengaruhi sifat fisika kimia tanah (Plaster, 2003). Ada beberapa sifat fisik tanah yang dapat mempengaruhi besarnya infiltrasi. Keterkaitan sifat fisik tanah dan infiltrasi sangat besar karena keduanya saling mempengaruhi. Sifat fisik tanah merupakan sifat yang bertanggung jawab atas peredaran udara, panas, air dan zat terlarut melalui tanah. Sifat fisik tanah yang penting antara lain adalah tekstur tanah, struktur, porositas dan stabilitas agregat (Hardjowigeno, 2003).

Berat Isi (BI) atau Bulk Density (BD), adalah suatu perbandingan antara massa padatan tanah dengan volume tanah, digunakan untuk mencirikan tanah, karena nilai perbandingan ini cukup stabil untuk jangka waktu yang lama biasanya dinyatakan dalam $\mathrm{gr} / \mathrm{cm}^{3}$ (Widianto dan Ngadirin, 2012). Kandungan bahan organik tanah yang dalam keseimbangan merupakan fungsi pertambahan serta perebutan karbon organik tanah (Sanchez, 1992). Tekstur tanah merupakan perbandingan kandungan partikel-partikel tanah primer berupa fraksi liat, debu dan pasir dalam suatu tanah (Syarief, 1986). Makroporositas adalah ruang pori besar dalam tanah. Jumlah pori makro diukur dengan 
metode pewarnaan menggunakan methylene blue, yang pada prinsipnya adalah melihat pola sebaran warna biru dari larutan methylen blue dalam profil tanah.

\section{BAHAN DAN CARA KERJA}

\section{Lokasi dan Waktu Penelitian}

Penelitian dilakukan pada bulan Januari sampai Mei tahun 2012 pada beberapa wilayah terseleksi di Kebun Raya Purwodadi, Pasuruan. Beberapa areal vak di kebun raya Purwodadi yang didominasi oleh satu spesies pohon yang terseleksi adalah di vak XIII H yaitu di dominasi oleh pohon Trembesi/Samanea saman, vak X.VIII.A yaitu didominasi oleh pohon jabon/Anthocephalus cadamba, dan vak XIX.A yang didominasi oleh pohon mahoni/Swietenia macrophylla.

\section{Bahan dan Alat}

Bahan dan alat yang digunakan dalam penelitian adalah penggaris, roll meter, plat besi berukuran $20 \times 20 \mathrm{~cm}$, double ring infiltrometer, cangkul, sekop,metilen blue, jerigen, stopwatch, ring sample, alat tulis, tali plastik, kantong plastik, kertas label, higrometer dan kamera.

\section{Cara Kerja}

Plot penelitian ditentukan dengan cara sengaja (purposive sampling) dengan memperhatikan faktor dominansi jenis tanaman pada areal tersebut. Pengujian hidrologi lahan yaitu penentuan laju dan kapasitas infiltrasi dengan menggunakan metode Ring Infiltrometer. Garis tengah cincin (stainless steel) bagian dalam $80 \mathrm{~cm}$, sedangkan tinggi $30 \mathrm{~cm}$. Infiltrometer dipasang pada setiap jenis tutupan vegetasi yang berbeda. Perhitungan besaran sifat fisika kimia tanah. Pengujian sampel tanah dilakukan antara lain berat Isi Tanah (BI), tekstur dan struktur tanah, kadar organik tanah, dan porositas tanah dilakukan pada Laboratorium Fisika Tanah universitas Brawijaya, Malang. Metode pengambilan contoh tanah, diambil pada kedalaman $20 \mathrm{~cm}$, karena kedalaman tersebut dianggap mampu mewakili karakteristik tanah dalam hubungannya dengan limpasan permukaan dan erosi (Utomo, 2004). Uji makroporositas diadakan langsung di lapangan, dilakukan dengan metode pewarnaan menggunakan larutan methylen blue. Semua pengujian infiltrasi dan sifat fisik tanah dilakukan pengulangan 4 kali untuk setiap sampel pohon yaitu di pinggir tajuk, di tengah tajuk, dan di dekat batang. Minipit dan plot untuk pengukuran makroporositas dan kondisi fisika kimia tanah diletakkan pada 4 lokasi di tiap sampel pohon, keempat plot ini mewakili keragaman distribusi akar yang ada seperti tepat di bawah batang, di pertengahan diameter tajuk, lokasi yang tepat di bawah tajuk, dan di luar tajuk.

Untuk mengetahui hubungan antara variabel-variabel terikat terhadap infiltrasi lahan, data yang telah ditabulasi diuji dengan análisis regresi berganda, dengan hubungan sebagai berikut:

$$
\mathrm{Y}=\mathrm{a} 0+\mathrm{b} 1 \mathrm{X} 1+\mathrm{b} 2 \mathrm{X} 2+\mathrm{bX} 3+\mathrm{b} 4 \mathrm{X} 4+\mathrm{b} 5 \mathrm{X} 5+\mathrm{b} 6 \mathrm{X} 6
$$

Di mana: $\mathrm{y}=$ infiltrasi (cm/jam), $\mathrm{x} 1$ = makroporositas (\%), $\mathrm{x} 2=$ bahan organik $(\%) \mathrm{x} 3=$ fraksi pasir $(\%), \mathrm{x} 4=$ fraksi debu (\%), x5 = fraksi liat (\%), dan x6 = Berat Isi Tanah $\left(\mathrm{g} / \mathrm{cm}^{3}\right), \mathrm{a}=$ intersep, $\mathrm{b}=$ slope garis kemiringan regresi (Drapper dan Sith, 1998)

Di dalam analisis regresi ini mengunakan uji asumsi terlebih dahulu yaitu kenormalan eror, homogenitas eror, dan uji multikolinearitas. Apabila terjadi variabel yang multikolinearitas, maka dapat dihilangkan satu atau beberapa variabel bebas yang dianggap memiliki korelasi tinggi dari model regresi. Setelah didapatkan persamaan regresi, kemudian dilanjutkan dengan uji F. Uji F atau uji koefisiensi regresi secara serentak digunakan untuk mengetahui pengaruh variabel independen secara serentak terhadap variabel dependen. Apakah pengaruhnya signifikan atau tidak. Hasil perhitungan nilai $\mathrm{F}$ di atas kemudian dilakukan perbandingan dengan nilai $\mathrm{F}$ tabel, apabila $\mathrm{F}$ hitung lebih besar lebih besar dari F tabel, maka dapat disimpulkan bahwa model berarti dan dapat dipergunakan secara simultan, kemudian dilanjutkan dengan koefisien determinasi $\left(\mathrm{R}^{2}\right)$ yang merupakan ukuran keterwakilan variabel dependen oleh variabel independen atau sejauh mana variabel independen dapat menjelaskan variabel dependen (Suharjo, 2008).

Proses-proses pengujian di atas merupakan proses pengujian terhadap model secara keseluruhan. Setelah itu akan dilanjutkan dengan proses pengujian model bagian demi bagian atau secara sendiri-sendiri yang dilakukan dengan uji T (Drapper dan Sith, 1998).

\section{HASIL}

Tiap plot di bawah tegakan Mahoni, Jabon, dan Trembesi memiliki nilai infiltrasi yang berbeda karena nilai variabelvariabel yang ikut mempengaruhinya berbeda pula.

Hasil pengukuran kondisi fisika kimia tanah dan nilai infiltrasi pada plot mahoni dapat dilihat pada Lampiran. Nilai reratanya disajikan pada Tabel 1.

Hasil pengukuran kondisi fisika kimia tanah dan nilai infiltrasi pada plot jabon dapat dilihat pada Lampiran. Nilai reratanya disajikan pada Tabel 2 . 
Hasil pengukuran kondisi fisikakimia tanah dan nilai infiltrasi pada plot trembesi dapat dilihat pada Lampiran. Nilai reratanya disajikan pada Tabel 3 .

\section{PEMBAHASAN}

Dalam penelitian ini diasumsikan nilai infiltrasi di tiap plot dipengaruhi oleh enam faktor, yaitu prosentase makroporositas, prosentase bahan organik, prosentase fraksi pasir, debu, dan liat sebagai penyusun tekstur, dan berat isi tanah, sehingga untuk selanjutnya dicari model infiltrasi dengan variabel-variabel bebas tersebut.

\section{A. Tegakan Mahoni}

Hasil analisis regresi menggunakan software SPSS versi 17.0, persamaan regresi dari model laju infiltrasi (Y) yang dibentuk adalah:

$\mathrm{Y}=-15,8+17,3 \mathrm{X} 1-1,09 \mathrm{X} 2+1,53 \mathrm{X} 3+0,001 \mathrm{X} 4$ $-21,3 \mathrm{X} 6$

Dari persamaan di atas, dapat diartikan bahwa setiap penambahan $1 \%$ makroporositas, dengan variabel lain bersifat konstan maka akan meningkatkan infiltrasi sebesar $17,3 \mathrm{~cm} / \mathrm{jam}$, setiap penambahan $1 \%$ bahan organik, dengan variabel lain bersifat konstan maka akan menurunkan infiltrasi sebesar $1.09 \mathrm{~cm} / \mathrm{jam}$, setiap penambahan $1 \%$ fraksi pasir dengan variabel lain bersifat konstan maka akan meningkatkan infiltrasi sebesar $1,53 \mathrm{~cm} / \mathrm{jam}$, setiap penambahan $1 \%$ fraksi debu, dengan variabel lain bersifat konstan maka akan meningkatkan infiltrasi sebesar sebesar $0,001 \mathrm{~cm} / \mathrm{jam}$, dan setiap penambahan $1 \mathrm{~g} / \mathrm{cm}^{2}$ Berat Isi dengan variabel lain bersifat konstan maka akan menurunkan infiltrasi sebesar 21,3 cm/jam. Pada persamaan tidak ditemukan faktor X5 (fraksi liat) ikut membentuk model karena dari analisa multikolinieritas diperoleh asumsi bahwa fraksi liat masih mengandung hubungan linear (saling berhubungan) dengan variabel yang lain.

Berdasarkan hasil pengujian menggunakan stastistik uji $\mathrm{F}$, variabel independen (X1, X2, X3,X4, dan X6) bersamasama berpengaruh signifikan terhadap infiltrasi (Y) dengan tingkat kebenaran 95\%. Nilai statistik uji t menunjukkan bahwa dengan tingkat kebenaran 95\% makroporositas (X1) berpengaruh nyata dalam model regresi dan fraksi pasir (X3) berpengaruh nyata dalam model regresi, sedangkan bahan organik (X2), fraksi debu (X4), dan Berat Isi tanah (X6) masing-masing tidak berpengaruh nyata dalam model regresi. Berdasarkan model yang terbentuk variabel yang berpengaruh nyata dan memberikan kontribusi paling besar dengan nilai koefisien $\beta$ yang paling tinggi variabel makroporositas.

Berdasarkan model yang telah diperoleh di atas, model infiltrasi pada tanaman mahoni akan bernilai negatif bila semua variabel (X1, X2, X3, X4, dan X6) diabaikan, hal ini menandakan bahwa bila tidak ada vegetasi dan sifatsifat fisika kimia yang berpengaruh terhadapnya lahan tersebut tidak mampu menginfiltrasi air hujan, bahkan akan menimbulkan limpasan permukaan sebesar 15,8 $\mathrm{cm} / \mathrm{jam}$. Model tersebut dapat dikatakan bersifat negatif, yaitu besaran X1, X2, X3, X4, dan X6 jika menunjukkan pengaruhnya secara bersama-sama maka nilai Y (Infiltrasi) akan negatif, hal tersebut menandakan infiltrasi tidak akan terjadi bahkan akan menimbulkan genangan air ataupun limpasan pada lahan bila nilai semua variabel

Tabel 1. Rerata Nilai Variabel Independen dan Dependen pada Model Infiltrasi Area Dominan Mahoni

\begin{tabular}{|c|c|c|c|c|c|c|c|}
\hline & $\mathrm{X} 1$ & $\mathrm{X} 2$ & X3 & $\mathrm{X} 4$ & X5 & $\mathrm{X} 6$ & $\mathbf{Y}$ \\
\hline Tegakan & $\begin{array}{c}\text { makroporositas } \\
(\%)\end{array}$ & $\begin{array}{l}\text { Bahan Organik } \\
\text { (\%) }\end{array}$ & $\begin{array}{l}\text { Pasir } \\
\text { (\%) }\end{array}$ & $\begin{array}{l}\text { Debu } \\
(\%)\end{array}$ & $\begin{array}{l}\text { Liat } \\
(\%)\end{array}$ & $\begin{array}{c}\mathrm{BI} \\
\left(\mathrm{g} / \mathrm{cm}^{3}\right)\end{array}$ & $\begin{array}{l}\text { Infiltrasi } \\
\text { (cm/jam) }\end{array}$ \\
\hline Mahoni & 2.48 & 4.74 & 8.33 & 49.00 & 42.67 & 0.92 & 65.35 \\
\hline
\end{tabular}

Tabel 2. Rerata Nilai Variabel Independen dan Dependen pada Model Infiltrasi Area Dominan Jabon

\begin{tabular}{lccccccc}
\hline \multirow{3}{*}{ Tegakan } & $\mathbf{X 1}$ & X2 & X3 & X4 & X5 & X6 & Y \\
\cline { 2 - 8 } & $\begin{array}{c}\text { makroporositas } \\
(\%)\end{array}$ & $\begin{array}{c}\text { Bahan Organik } \\
(\%)\end{array}$ & $\begin{array}{c}\text { Pasir } \\
(\%)\end{array}$ & $\begin{array}{c}\text { Debu } \\
(\%)\end{array}$ & $\begin{array}{c}\text { Liat } \\
(\%)\end{array}$ & $\begin{array}{c}\text { BI } \\
\left(\mathbf{g} / \mathbf{c m}^{3}\right)\end{array}$ & $\begin{array}{c}\text { Infiltrasi } \\
(\mathbf{c m} / \mathbf{j a m})\end{array}$ \\
\hline Jabon & 0.59 & 3.66 & 10.67 & 43.83 & 46.33 & 1.00 & 16.33 \\
\hline
\end{tabular}

Tabel 3. Rerata Nilai Variabel Independen dan Dependen pada Model Infiltrasi Area Dominan Trembesi

\begin{tabular}{|c|c|c|c|c|c|c|c|}
\hline & $\mathrm{X} 1$ & $\mathrm{X} 2$ & $\mathrm{X3}$ & $X 4$ & $\mathrm{X5}$ & $\mathrm{X} 6$ & $\mathbf{Y}$ \\
\hline Tegakan & $\begin{array}{c}\text { makroporositas } \\
(\%)\end{array}$ & $\begin{array}{c}\text { Bahan Organik } \\
(\%)\end{array}$ & $\begin{array}{l}\text { Pasir } \\
(\%)\end{array}$ & $\begin{array}{l}\text { Debu } \\
(\%)\end{array}$ & $\begin{array}{l}\text { Liat } \\
\text { (\%) }\end{array}$ & $\begin{array}{c}\mathrm{BI} \\
\left(\mathrm{g} / \mathrm{cm}^{3}\right)\end{array}$ & $\begin{array}{l}\text { Infiltrasi } \\
\text { (cm/jam) }\end{array}$ \\
\hline 0.50 & 3.94 & 31.83 & 39.00 & 29.17 & 1.17 & 12.93 & 0.50 \\
\hline
\end{tabular}


yang mempengaruhinya cuma satu (1) satuan. Untuk dapat menimbulkan peristiwa infiltrasi, hal yang harus dilakukan untuk adalah melakukan peningkatan terhadap besaran makroporositas dan penurunan Berat Isi tanah sebagai variabel yang memiliki nilai koefisien regresi yang paling besar. Dapat diasumsikan bila kita menambahkan nilai X2 (prosentase bahan organik) 1 satuan, hasilnya tidak akan menurunkan nilai infiltrasi, walaupun koefisien regresi X2 negatif, hal ini dikarenakan dari uji lanjut (UJI F) pengaruh yang ditemukan adalah pengaruh yang bersamasama bukan sendiri-sendiri. Penambahan prosentase bahan organik tersebut pastinya akan membuat nilai variabel lain ikut terpengaruh (seperti peningkatan makroporositas dan penurunan nilai Berat Isi Tanah), sehingga tidak akan didapatkan nilai infiltrasi yang negatif. Berdasarkan teori, tidak akan terjadi penurunan laju infiltrasi karena peningkatan nilai kandungan bahan organik tanah. Sesuai dengan yang dinyatakan Tjahyono, et al. (2005) bahwa bahan organik merupakan pemasukan ke dalam tanah di mana terjadi penguraian unsur hara karena mikroorganisme, retensi air, penambahan porositas dan perubahan struktur tanah. Dari keempat peristiwa itu tentunya akan membuka jalan yang lebih banyak dan luas bagi air yang akan masuk ke dalam tanah. Sebaliknya peningkatan nilai infiltrasi terjadi bila ada penurunan nilai berat isi tanah. Berat isi tanah merupakan kepadatan tanah, semakin tinggi nilai BI makin padat suatu tanah sehingga porositas tanah menjadi rendah. Bobot isi dan porositas tanah dapat berubah dan beragam tergantung pada keadaan struktur tanah, khususnya dalam hubungannya dengan proses pemadatan tanah dan penambahan bahan organik (Widiarto, 2008). Bila diasumsikan ada penambahan nilai bahan organik pada lahan, tentunya akan mengakibatkan organisme tanah semakin aktif merombak unsur hara dalam tanah sehingga agregat tanah jadi terganggu dan membentuk ruang pori yang lebih banyak dan berat isi bertambah. Dari uraian tersebut maka dapat diyakinkan bahwa penambahan bahan organik tanah pada model tidak akan menghasilkan nilai infiltrasi yang negatif karena secara bersama-sama akan diikuti oleh peningkatan atau penurunan variabel yang lain.

Beberapa bentuk kehidupan seperti cacing, rayap, dan semut berperan penting dalam pengangkutan tanah. Faktor yang mempengaruhi bahan organik tanah yaitu, kedalaman tanah yang menentukan kadar bahan-bahan organik yang terdapat pada kedalaman $20 \mathrm{~cm}$ dan makin ke bawah makin berkurang. Mikroorganisme dalam tanah mempunyai peranan dalam proses peruraian bahan organik menjadi unsur hara dapat diserap oleh akar tanaman dan pembentukan humus. Cacing tanah sangat aktif dalam peruraian (dekomposisi) serasah. Rayap-rayap makan sisasisa bahan organik. Dalam penelitian ini banyak ditemui binatang dan mikroorganisme tersebut, terutama pada tanah mahoni.

Menurut Widiarto (2008), bahan organik dapat menurunkan BI dan tanah yang memiliki nilai BI kurang dari satu merupakan tanah yang memiliki bahan organik tanah sedang sampai tinggi. Selain itu, Nilai BI untuk tekstur berpasir antara $1,5-1,8 \mathrm{~g} / \mathrm{m}^{3}$. Nilai BI untuk tekstur berlempung antara $1,3-1,6 \mathrm{~g} / \mathrm{m}^{3}$ dan Nilai BI untuk tekstur berliat antara $1,1-1,4 \mathrm{~g} / \mathrm{m}^{3}$ merupakan nilai BI yang dijumpai pada tanah yang masih alami atau tanah yang tidak mengalami pemadatan. Nilai BI pada tanah mahoni yang cukup kecil $0,92 \mathrm{~g} / \mathrm{m}^{3}$ mengindikasikan tanah mengandung bahan organik yang cukup tinggi.

Dari persamaan hasil regresi dapat dilihat bahwa faktor yang mempengaruhi laju infiltrasi adalah X1, X2, X3, X4, dan X6 dengan nilai koefisien determinasi adalah $\mathrm{R}^{2}=$ 0,925 dapat diinterpretasikan bahwa sebesar $92,5 \%$ variabel y dipengaruhi oleh makroporositas, bahan organik, fraksi pasir, fraksi debu, dan berat isi sedangkan sebesar 7.5\% dipengaruhi oleh faktor lain.

\section{B. Tegakan Jabon}

Hasil analisis regresi menggunakan software SPSS versi 17.0, persamaan regresi yang dibentuk dari model laju infiltrasi (Y) adalah:

\section{$\mathrm{Y}=-108+53,0 \mathrm{X} 1-0,68 \mathrm{X} 2+5,27 \mathrm{X} 3-0,470 \mathrm{X} 4+$ $59,7 \times 6$}

Dari persamaan di atas, dapat diartikan bahwa setiap penambahan $1 \%$ makroporositas, dengan variabel lain bersifat konstan maka akan meningkatkan infiltrasi sebesar $53 \mathrm{~cm} / \mathrm{jam}$, setiap penambahan $1 \%$ bahan organik, dengan variabel lain bersifat konstan maka akan menurunkan infiltrasi sebesar $0,68 \mathrm{~cm} / \mathrm{jam}$, setiap penambahan $1 \%$ fraksi pasir dengan variabel lain bersifat konstan maka akan meningkatkan infiltrasi sebesar $5,27 \mathrm{~cm} / \mathrm{jam}$, setiap penambahan $1 \%$ fraksi debu, dengan variabel lain bersifat konstan maka akan menurunkan infiltrasi sebesar sebesar $0,47 \mathrm{~cm} / \mathrm{jam}$, dan setiap penambahan $1 \mathrm{~g} / \mathrm{cm}^{2}$ Berat Isi dengan variabel lain bersifat konstan maka akan meningkatkan infiltrasi sebesar $59,7 \mathrm{~cm} / \mathrm{jam}$

Berdasarkan hasil pengujian menggunakan stastistik uji F menyatakan bahwa variabel independen (X1,X2, X3, $\mathrm{X} 4$ dan X6) bersama-sama berpengaruh signifikan terhadap infiltrasi (Y) dengan tingkat kebenaran 95\%. Nilai statistik uji $t$ menunjukkan bahwa dengan tingkat kebenaran 95\% 
makroporositas (X1) berpengaruh nyata dalam model regresi, sedangkan bahan organik (X2), fraksi pasir (X3), fraksi debu (X4), dan Berat Isi tanah (X6) masing-masing tidak berpengaruh nyata dalam model regresi. Berdasarkan model yang terbentuk variabel yang berpengaruh nyata dan memberikan kontribusi paling besar dengan nilai koefisien $\beta$ yang paling tinggi variabel makroporositas.

Dari persamaan hasil regresi dapat dilihat bahwa faktor yang mempengaruhi laju infiltrasi adalah $\mathrm{x} 1, \mathrm{x} 2, \mathrm{x} 3, \mathrm{x} 4$ dan $\mathrm{x} 6$ dengan nilai koefisien determinasi adalah $\mathrm{R}^{2}=89,3 \%$, dapat diinterpretasikan bahwa sebesar $89,3 \%$ variabel y dipengaruhi oleh makroporositas, bahan organik, fraksi pasir, fraksi debu, dan berat isi sedangkan sebesar 10,7\% dipengaruhi oleh faktor lain.

\section{Tegakan Trembesi}

Hasil analisis regresi menggunakan software SPSS versi 17.0, persamaan regresi yang dibentuk dari model laju infiltrasi (Y) adalah:

$\mathrm{Y}=-20,1+17,4 \mathrm{X} 1-1,06 \mathrm{X} 2+1,57 \mathrm{X} 3+0,082 \mathrm{X} 4$ $-21,6 \mathrm{X} 6$

Dari persamaan di atas, dapat diartikan bahwa setiap penambahan $1 \%$ makroporositas, dengan variabel lain bersifat konstan maka akan meningkatkan infiltrasi sebesar $17,4 \mathrm{~cm} / \mathrm{jam}$, setiap penambahan $1 \%$ bahan organik, dengan variabel lain bersifat konstan maka akan menurunkan infiltrasi sebesar $1,06 \mathrm{~cm} / \mathrm{jam}$, setiap penambahan $1 \%$ fraksi pasir dengan variabel lain bersifat konstan maka akan meningkatkan infiltrasi sebesar $1,57 \mathrm{~cm} /$ jam, setiap penambahan $1 \%$ fraksi debu, dengan variabel lain bersifat konstan maka akan meningkatkan infiltrasi sebesar 0,082 $\mathrm{cm} / \mathrm{jam}$, dan setiap penambahan $1 \mathrm{~g} / \mathrm{cm}^{2}$ Berat Isi dengan variabel lain bersifat konstan maka akan menurunkan infiltrasi sebesar 21,6 cm/jam

Berdasarkan hasil pengujian menggunakan stastistik uji $\mathrm{F}$ menyatakan bahwa variabel independen (X1, X2, $\mathrm{X} 3, \mathrm{X} 4$ dan X6) bersama-sama berpengaruh signifikan terhadap infiltrasi $(\mathrm{Y})$ dengan tingkat kebenaran 95\%. Nilai statistik uji $\mathrm{t}$ menunjukkan bahwa dengan tingkat kebenaran 95\% makroporositas (X1) berpengaruh nyata dalam model regresi dan fraksi pasir (X3) berpengaruh nyata dalam model regresi, sedangkan bahan organik (X2), fraksi debu (X4), dan Berat Isi tanah (X6) masing-masing tidak berpengaruh nyata dalam model regresi. Berdasarkan model yang terbentuk variabel yang berpengaruh nyata dan memberikan kontribusi paling besar dengan nilai koefisien $\beta$ yang paling tinggi variabel makroporositas.

Berdasarkan model yang telah diperoleh di atas, model infiltrasi pada tanaman trembesi akan bernilai negatif bila semua variabel (X1, X2, X3, X4, dan X6) diabaikan, hal ini menandakan bahwa bila tidak ada vegetasi dan sifatsifat fisika kimia yang berpengaruh terhadapnya lahan tersebut tidak mampu menginfiltrasi air hujan, bahkan akan menimbulkan limpasan permukaan sebesar 20,1 $\mathrm{cm} / \mathrm{jam}$. Seperti juga halnya pada mahoni, penambahan bahan organik tanah pada model tidak akan menghasilkan nilai infiltrasi yang negatif karena secara bersama-sama akan diikuti oleh peningkatan atau penurunan variabel yang lain. Bahan organik, fraksi pasir, debu, dan BI tidak adan berpengaruh bila tidak berada secara bersama-sama, seperti hasil pada uji F.

Berdasarkan persamaan hasil regresi dapat dilihat bahwa faktor yang mempengaruhi laju infiltrasi adalah $\mathrm{x} 1, \mathrm{x} 2, \mathrm{x} 3, \mathrm{X} 4$, dan $\mathrm{x} 6$ dengan nilai koefisien determinasi adalah $\mathrm{R}^{2}=92.6 \%$, dapat diinterpretasikan bahwa sebesar 92.6\% variabel y dipengaruhi oleh makroporositas, bahan organik, fraksi pasir, fraksi debu, dan berat isi sedangkan sebesar 7,4\% dipengaruhi oleh faktor lain.

Fraksi pasir pada tanah plot yang dominan tanaman trembesi jumlahnya lebih besar dibandingkan pada plot lain dan dari tabel diketahui bahwa fraksi pasir sebagai faktor $\mathrm{X} 3$ berpengaruh nyata dalam mempengaruhi infiltrasi. Partikel pasir ukurannya jauh lebih besar dan memiliki luas permukaan yang kecil dibandingkan dengan partikel debu dan liat. Oleh karena itu, maka peranan partikel pasir dalam ikut mengatur sifat-sifat kimia tanah adalah kecil sekali, tetapi fungsi utamanya adalah sebagai penyokong tanah dalam mana disekelilingnya terdapat partikel-partikel liat dan debu yang lebih aktif (Utomo, 2004. Liat kaya akan pori halus dan miskin akan pori besar. Sebaliknya fraksi pasir banyak mengandung pori besar dan sedikit pori halus. Dengan demikian kapasitas infiltrasi pada tanah-tanah pasir jauh lebih besar daripada tanah liat. Tanah-tanah yang bertekstur kasar menciptakan struktur tanah yang ringan. Sebaliknya tanah-tanah yang terbentuk atau tersusun dari tekstur tanah yang halus menyebabkan terbentuknya tanah-tanah yang bertekstur berat. Tanah dengan struktur tanah yang berat mempunyai jumlah pori halus yang banyak dan miskin akan pori besar. Sebaliknya tanah yang ringan mengandung banyak pori besar dan sedikit pori halus. Dengan demikian kapasitas infiltrasi dari kedua jenis tanah-tanah tersebut akan berbeda pula, yaitu tanah yang berstruktur ringan kapasitas infiltrasinya akan lebih besar dibandingkan dengan tanah-tanah yang berstruktur berat (Utomo, 2004). Tanah-tanah yang mengandung jumlah liat tinggi dapat tersuspensi oleh butir-butir hujan yang jatuh menimpanya dan pori-pori lapisan permukaan akan tersumbat oleh butir-butir liat, sehingga aliran permukaan dan erosi yang hebat (Harahap, 
2007). Pada kenyataannya nilai infiltrasi pada plot trembesi kecil, walaupun fraksi pasirnya besar ini dapat dijelaskan dari faktor makroporositas yang ternyata perannya lebih mendominan. Prosentase makroporositas pada plot trembesi yang paling kecil dibandingkan dengan kedua pohon yang lain menyebabkan nilai infiltrasinya juga rendah.

Berdasarkan ketiga model persamaan laju infiltrasi yang dihasilkan, diperoleh kesimpulan bahwa faktor sifat fisika tanah yang paling berpengaruh terhadap infiltrasi adalah prosentase makroporositas. Distribusi pori tanah sangat berpengaruh terhadap laju infiltrasi, tanah dengan jumlah pori makro yang besar akan mempunyai laju infiltrasi yang lebih tinggi dibandingkan tanah dengan pori makro kecil meskipun jumlah total pori sama. Peran pori makro ini ibarat corong jalan masuknya air ke dalam tanah. Seperti yang dikemukakan Hairiah, et al. (2004) bahwa hubungan antara pori makro dengan infiltrasi konstan mempunyai kecenderungan positif, di mana semakin tinggi makroporositas tanah maka infiltrasi konstan juga semakin meningkat.

Berdasarkan Nilai rata-rata makroporositas ke tiga pohon memberikan hasil yang berbeda, uji lanjut dilakukan dengan BNT dan memperoleh hasil bahwa pohon trembesi dan jabon mempunyai makroporositas yang sama. Pohon mahoni memberikan makroporositas yang berbeda nyata dibandingkan jabon dan trembesi. Makroporositas yang terbesar adalah pohon mahoni dengan nilai rata-rata $2.48 \%$. Jumlah pori makro tanah pada bidang irisan vertikal ini memberikan gambaran hubungan pori makro antar lapisan tanah, semakin tinggi jumlah pori makro pada bidang irisan vertikal maka semakin cepat pergerakan air di dalam profil tanah (Hillel, 1982).

Tabel 4. Nilai Prosentase Makroporositas Mahoni, Jabon, dan Trembesi

\begin{tabular}{cccc}
\hline Ulangan & Mahoni & Jabon & Trembesi \\
\hline 1 & 2.55 & 0.42 & 0.56 \\
2 & 2.79 & 0.58 & 0.52 \\
3 & 2.66 & 0.64 & 0.53 \\
4 & 2.82 & 0.69 & 0.42 \\
5 & 1.5 & 0.58 & 0.58 \\
6 & 2.56 & 0.6 & 0.4 \\
\hline Rerata & $2.48^{\mathrm{b}}$ & $0.585^{\mathrm{a}}$ & $0.502^{\mathrm{a}}$ \\
\hline
\end{tabular}

Keterangan:

Pemberian Notasi yang Berbeda Menunjukkan Perbedaan yang Nyata Antar Perlakuan $(p<0.05)$.
Makroporositas atau pori makro dapat dipengaruhi oleh berbagai faktor, seperti celah atau ruang yang terbentuk dari pemadatan matrik tanah, juga adanya gangguan aktivitas perakaran dan hewan tanah yang merombak seresah yang dihasilkan oleh vegetasi yang berada di atasnya. Dalam penelitian Darmayanti, et al (2012) telah mengemukakan di antara jabon dan trembesi, mahonilah yang memiliki seresah yang lebih banyak dan lebih lama terdekomposisi serta perakaran yang lebih rapat, selain itu karena pada plot mahoni banyak ditumbuhi berbagai jenis ground cover, sehingga variasi perakaran yang tumbuh di atas tanah menjadi lebih banyak.

Dari hasil penelitian diperoleh kesimpulan bahwa nilai laju infiltrasi dimodelkan dari fungsi $\mathrm{y}=$ infiltrasi, $\mathrm{x} 1=$ makroporositas $\mathrm{x} 2=$ bahan organik $\mathrm{x} 3=$ fraksi pasir, $\mathrm{x} 4=$ fraksi debu, $\mathrm{x} 5$ dan $\times 6=$ Berat Isi Tanah menghasilkan tiga model untuk plot yang didominasi 3 tanaman yang berbeda. Makroporositas selalu berpengaruh secara nyata terhadap model. Dari persamaan yang dihasilkan, peningkatan $1 \%$ makroporositas, dengan variabel lain bersifat konstan maka akan meningkatkan infiltrasi sebesar $17,3 \mathrm{~cm} / \mathrm{jam}$ pada mahoni, $53 \mathrm{~cm} / \mathrm{jam}$ pada jabon, dan 17,4 cm/jam pada trembesi. Berdasarkan nilai makroporositas ketiga pohon, nilai yang tertinggi adalah terletak pada tanaman mahoni, karena dipengaruhi perakaran dan potensi seresah mahoni.

\section{KEPUSTAKAAN}

Asdak, C. 2002. Hidrologi dan Daerah Pengelolaan Aliran Sungai. Gadjah Mada University Press. Yogyakarta.

Darmayanti, A.S. 2012. Karakteristik Pohon dalam Pengaruhnya terhadap Infiltrasi.

Air Hujan di Beberapa Vak Kebun Raya Purwodadi. Program Studi Pengelolaan Sumber Daya Lingkungan, Tesis. Universitas Brawijaya. Malang.

Drapper, dan Sith, 1998. Applied Regression Analysis. Willey and Sons. New York.

Hairiah, K., Widianto, Suprayogo, D., Widodo, R.H., Purnomosidhi, P., Rahayu, S., dan Noordwijk, M.V. 2004. Ketebalan Seresah sebagai Indikator Daerah Aliran Sungai (DAS) Sehat. World Agroforestry Centre, ICRAF SE Asia, Bogor. $41 \mathrm{p}$

Harahap, E.M. 2007. Kelapa Sawit Penuhi Syarat Jadi Tanaman Konservasi. www.antara.co.id. Diakses tanggal 10 Juli 2012.

Hardjowigeno, S. 2003. Ilmu Tanah. Akademikan Pressindo. Jakarta.

Hillel, D. 1982. Fundamentals of Soil Physics. Academic Press Inc. London. 
Sanchez, P.A. 1992. Properties and Management of Soil in Tropics. John Willey \& Sons. New York.

Suharjo, B. 2008. Analisa Regresi Terapan dengan SPSS. Graha Ilmu. Bandung.

Syarief, 1986. Konservasi Tanah dan Air. Pustaka Buana. Bandung.

Tjahyono, T. Bangun Muljo Sukojo dan Wahono, 2005. Pemanfaatn Teknologi Penginderaan Jauh untuk Pemetaan Kandungan Bahan Organik Tanah. Teknologi Makara, 6(3).
Utomo, W.H. 2004. Konservasi Tanah di Indonesia. Rajawali Press. Jakarta

Widianto dan Ngadirin, 2012. Pedoman Praktikum: Pengantar Fisika Tanah. Laboratorium.

Fisika Tanah. Jurusan Tanah. Fakultas Pertanian. Universitas Brawijaya. Malang.

Widiarto, 2008. Pengantar Ilmu Tanah. PT. Rineka Cipta Jakarta. 